\title{
DETERMINANTS OF THE SELECTION OF TRAVEL AGENCIES ON POLISH TOURIST SERVICES MARKET
}

\section{Anna Mazurek-Kusiak ${ }^{1}$}

1 University of Life Sciences, Department of Tourism and Recreation, Poland, ORCID: 0000-0002-3786-8861,
anna.mazurek@up.Iublin.pl.

Abstract: The aim of the paper is to present differences regarding the sources of searching for information about the travel agency, the determinants which the respondents follow when purchasing tourist events in a given travel agency and the main purposes of the journey, taking into account the respondents' place of residence. The research used the method of a diagnostic survey using the direct questionnaire technique. The research was carried out in 2017 in various regions of Poland among residents using off-line services of travel agencies (tourism organizers). A fivepoint Likert scale was used to measure attitudes. The size of the research sample was based on the size of the adult population of Poland. A layered selection was used, in which respondents were selected on the basis of availability, taking into account the criteria related to adulthood, gender and age. Statistica 13.1 PL was used for statistical calculations. The discriminant function analysis was used. The tourist services market is a very variable and difficult to predict market. Research of the author of the paper indicates that for people living in villages and small towns the most important thing is the recommendation of a travel agency by friends, a well-known brand to which tourists are convinced and a price. For people from medium-sized cities, location of travel agency is very important, and the inhabitants of large cities pay particular attention to the rich offer of travel agencies and adjustment of the tourist event to individual needs of clients. The least important is the equipment and decoration of the office.

Keywords: Tourist market, travel agencies, Poland, tourists.

JEL Classification: M31, M39, Z33.

APA Style Citation: Mazurek-Kusiak, A. (2020). Determinants of the Selection of Travel Agencies on Polish Tourist Services Market. E\&M Economics and Management, 23(1), 156-166. https://doi.org/10.15240/tul/001/2020-1-011

\section{Introduction}

The tourist services market is a very variable and difficult to predict market (Chen \& Kang, 2015) that reacts quickly to factors and turmoil occurring in the international, national and local environment. Impact of these factors is evident both on the supply and on the demand side (Zdon-Korzeniowska \& Rachwał, 2011). Studies by Millana and Esteban (2004), Silva and Gonçalves (2016) and Chih-Wen (2016) showed that customers are not loyal to their travel agencies. Changing the organizer of tourist services is not a problem for tourists, nor does it raise any resistance such as may occur, for example, when changing the telephone operator, bank or energy supplier. Thus, it is more difficult for travel agencies to acquire regular customers than for other service companies. In addition, they must adapt the offer more precisely to the needs of customers to convince them to purchase the services offered (Rudawska, 2010), therefore it is so important to know the main goals of tourist trips, customers' needs and determinants, that guide the selection of the organizer of a tourism. In order to gain their trust, they must choose appropriate communication channels to establish a dialogue with the customer, promote their own brand and the tourist products they sell. It should also be remembered that in 
the tourism industry, there are no significant elements of competitive advantage that appear in enterprises from the IT or pharmaceutical sector, the profitability of which is $30-40 \%$, but the profitability of travel agencies is at the level of several percent (Piotrowska, 2007). Economic recession, terrorist threats, military threats, civil wars, ecological catastrophes, or epidemics cause a decline in the profitability of tourism enterprises and a decrease in travels, which results in the growing bankruptcies of travel agencies.

The aim of the paper is to present differences regarding the sources of searching for information about the travel agency, the determinants which the respondents follow when purchasing tourist events in a given travel agency and the main purposes of the journey, taking into account the respondents' place of residence. The paper hypothesizes that customers coming from villages, small, medium and large cities, have different expectations towards travel agencies, therefore tourism organizers and agents should use different models of reaching potential clients.

\section{Literature Review}

The role of a travel agency is changing in the modern world, which at the same time requires the use of new models in customer acquisition and matching supply to existing demand (Castillo-Manzano \& López-Valpuesta, 2010; Del-Chiappa, 2013; Frias et al., 2008; Galhanone et al., 2010).

Opening of Poland's borders at the beginning of the 1990s resulted in the establishment of many small travel agencies on Polish market, dealing with the organization of foreign and domestic trips. However, these offices did not have experience or high capital. At the same time, international tour operators opened their branches on Polish market by creating a sales network of their own tourist events (Mańko, 2012). The wave of growth in the number of travel agencies has led the state to establish legal regulations in this area. Act of August 29, 1997 on tourist services, Dz.U. 1997 No. 133 pos. 884, effective in Poland until July 1,2018 , amended by Directive 2015/2302/EU of November 25, 2015, into two acts: Act of August 29, 1997 on hotel services and services of tour guides and tourist guides. Dz.U. 1997 No. 133 pos. 884 and the Act of November 24, 2017 on tourist events and related tourist services, Dz.U. 2017 pos. 2361 . The Act temporarily stabilized the situation on the Polish tourism market. In 2000, there were 2792 organizers and travel agents in Poland, and two years later this number increased to 3650 (Fig. 1).

After Poland's accession to the EU in 2004, organizers of tourist events faced the need to cope with the competition of foreign travel agencies, the prices of insurance policies increased, which resulted in the first wave of bankruptcies. At that time, as many as 660 organizers and travel agents were removed from the entrepreneurs' records (Fig. 2). Since 2006, the number of travel agencies has been slowly but steadily growing, however, the situation was halted in 2010 by a series of ecological events and catastrophes. These included air traffic paralysis caused by volcanic

\section{Fig. 1: Number of tour operators and tourist brokers on the Polish market in 2000-2017}

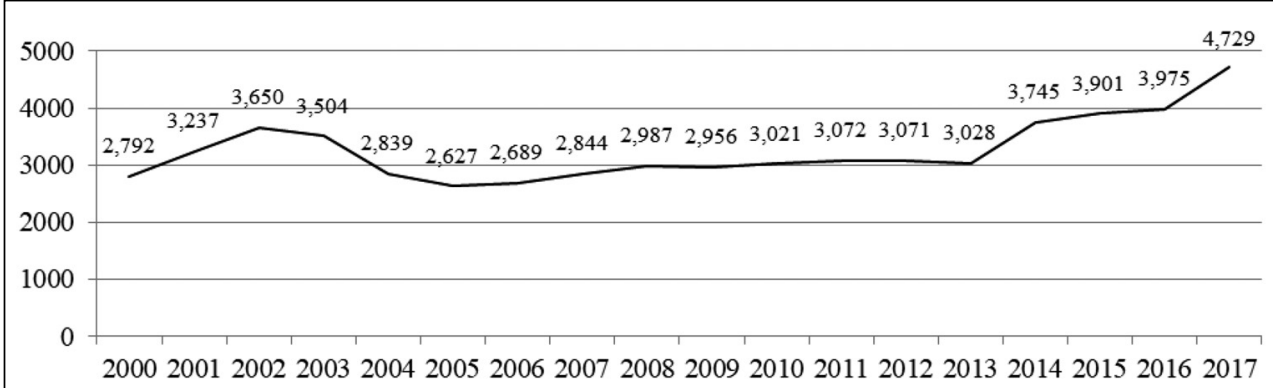




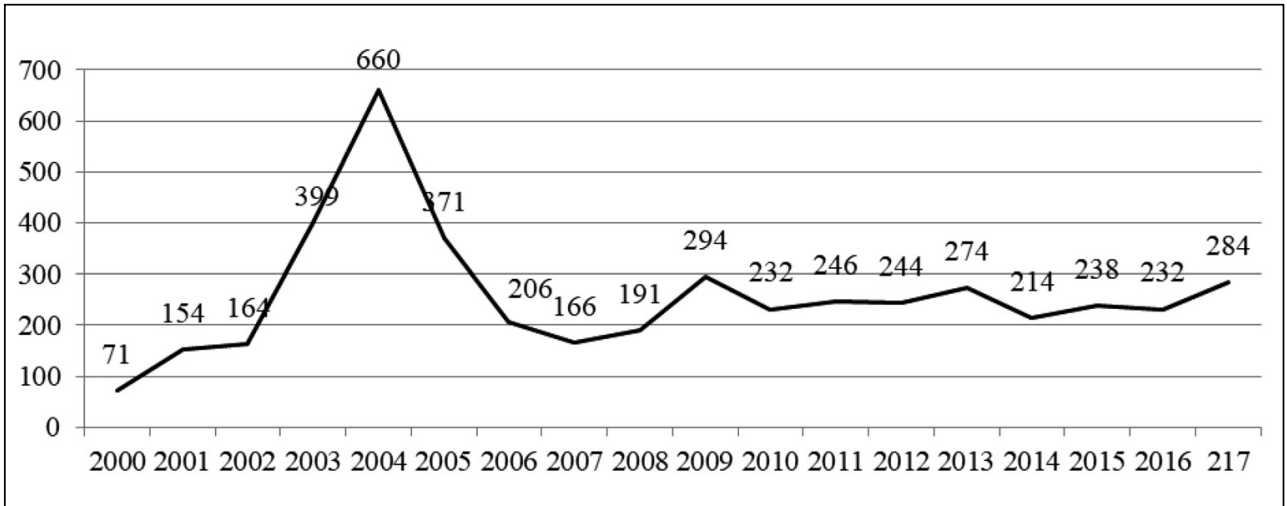

Source: own study based on Statistics CEOTiPT, 2018

ash after a volcanic eruption in Iceland, the economic and political crisis in Greece, terrorist attacks, high exchange rates of euro and dollar. Furthermore, in 2011 a revolution broke out in some countries of North Africa, which caused a decrease in trips to very popular countries for Poles, namely Egypt and Tunisia (Sobolewski \& Bober, 2013). In 2011, new regulations concerning bank and insurance guarantees came into force, which also influenced the financial condition of Polish tour operators and travel agents. The result was many bankruptcies of travel agencies that already had an established position on Polish market. In 2012, 244 travel agencies suspended their operations, a year later as many as 274 , and in 2017 up to 284 (Fig. 2). Tour operators and tourism agents are also currently struggling to stay on the market due to the numerous competition, high flexibility of demand for tourist services and the uncertainty of the political, economic and ecological environment.

Competitiveness in the sector is sustained by strategies that focus on preparing offers tailored to customer needs, introducing technical innovations in customer service, observing and analyzing changing demand, and responding quickly to changes in the environment of travel agencies (Millana \& Esteban, 2004).

Studies on up-to-date literature have shown that travel agencies usually use three models that will allow them to gain a client and achieve a better position in the market than the competition. The first model focuses on high quality customer service (for instance Kuo et al., 2014; Lam \& Zhang, 1999; Lai, 2014; Martínez-Caro \& Martínez-Garcia, 2008; Ryan \& Cliff, 1997). The second model focuses on analyzing the demand and needs of customers and adapting relevant offers to clients (Del Chiappa, 2013; llbery et al., 2007). The third group of researchers shows that models focusing on cooperation with business partners (mainly hotels and airlines) are the most important (Barros \& Matias, 2006; Fuentes \& Alvarez-Suarez, 2012; Köksal \& Aksu, 2007; Lacalle, 2013).

Also, according to O'Connor (1999), the travel agency market is characterized by three-way business relations: travel agencies act as an intermediary between tourists and providers of individual services (transport, accommodation and meals). To remain secure in the distribution chain, travel agencies should develop a high level of communication and cooperation with clients (Gustafson, 2012), as well as focus on adapting their offers and requirements to the needs of tourists and should be an advisor during the planning of travel (Bennet, 1993). Research by Tse and Wilton (1990) and Jayanti and Jackson (1991) also confirm that customer's satisfaction with the purchase process is the most important for the acquisition of clients by travel agencies. These activities will help to win loyalty and trust of tourists. 
It should also be noted that in the last two decades, the internet has changed the role of travel agencies in the tourism services market. Currently, they are information points on tourist services. In addition, the Internet makes it easier to search information and compare the offers of various travel agencies (Del Chiappa, 2013; Huang et al., 2011; Özturan \& Roney, 2004; Silva \& Gonçalves, 2016), which makes competition worse and the role of traditional travel agencies reduced. This increases the need for research upon customer segmentation and indicates the need to learn the factors that guide tourists when choosing specific travel agencies (Aguiar-Quintana et al., 2016). Kumar et al. (2013) and Pan et al. (2012) also confirm that there is a need for more research in the field of customer segmentation and determinants of their choice of the service provider. Understanding the factors that guide customers when choosing a travel agency can help to ensure customer loyalty (Gonçalves \& Sampaio, 2012). It is also important to recognize the travel destinations of individual customer segments, so that adjusting the offer to the expectations of potential tourists can be more accurate (Wang \& Wang, 2010).

There is no research in the world literature on customer segmentation from the point of view of the residence place. And pilot studies have shown that tourists in Poland show significant differences in the perception of tourist services due to the fact whether they live in a large urban area, a small town or a village (Mazurek-Kusiak, 2017). Therefore, travel agents should use different strategies depending on their location. This is important on Polish market, where the financial condition of travel agencies is not the best, because only every fifth Pole traveling abroad uses the services of tourism organizers, and only every fifteenth when traveling around the country. In addition, many travel agencies bankrupt and declare bankruptcy (ByszewskaDawidek, 2015). For this reason, it is important to properly segment customers and adapt the offer and promotion to each segment.

Obtained empirical results of the study upon travel agents market enable the assessment of the actual state and serve the correct formulation of the principles of government policies and business strategies. They also play an important role in development of the travel agency sector, which is an inseparable element of tourism development.

\section{Study Methods}

The research used the method of a diagnostic survey using the direct questionnaire technique. An original questionnaire was prepared. The research was carried out in 2017 in various regions of Poland among residents using off-line services of travel agencies (tourism organizers). A five-point Likert scale was used to measure attitudes. The size of the research sample was based on the size of the adult population of Poland. The population structure was defined as $0.0033 \%$ of the entire population of Poland (in this voivodship). A layered selection was used, in which respondents were selected on the basis of availability, taking into account the criteria related to adulthood, gender (women accounted for $56.51 \%$ and men $43.49 \%$ ) and age $(29.25 \%$ of respondents was up to 30 years old, $22.26 \%$ in the age range $31-45,28.02 \%$ in the group from 46 to 60 years, and $20.47 \%$ in the age of 61 and more). When calculating the representative sample size, the confidence level was set at 0.95 , the estimated fraction size at 0.05 , while the maximum error was set at 0.05 . Respondents completed 1,121 questionnaires, of which 1,060 were used for statistical calculations after verification (Tabachnik \& Fidell, 1996; Mazurek-Kusiak, 2017).

Statistica 13.1 PL was used for statistical calculations. In order to decide which variables distinguish four naturally emerging groups, the discriminant function analysis was used, because it allows to study differences between groups of objects based on a set of selected independent variables (predictors). In addition, it is used in correlation studies, i.e. when causal relationships between variables are not well recognized. The studies used a classification function in the form of calculating the coefficients that were defined for each group of variables. Prior to the analysis, multivariate normality was verified by checking each variable for normality of distribution. It was assumed that variable variance matrices are homogeneous in groups. Slight deviations were not so important due to the large number of groups. Statistically significant differences were those, for which the probability of randomness was less than 0.05 .

\section{Study Results}

At the beginning, a study was conducted on the sources of information about the travel agency, taking into account respondents' place 
of residence. The model included 3 out of 8 communication channels with the client, to which the respondents draw the main attention. Statistically significant discriminant differences in the surveyed groups regarding the search for information about a travel agency were: internet and communication via social media $(F=11.7876, p<0.001)$, advertising in TV media $(F=3.7985, p=0.010)$, marketing whispered $(F=3.1506, p=0.024)$ (Tab. 2). The model did not qualify: travel agency websites $(F=1.0767$, $p<0.358)$, leaflets, brochures $(F=1.7818$, $p<0.147)$, tourist fairs $(F=0.4132 ; p<0.744)$, advertisement in radio and press $(\mathrm{F}=2.4385$, $p<0.063$ ).

The highest values of the classification function were achieved by the factor: travel agency communication with a potential client via internet, including social media. This factor is most important for residents of large cities over 100,000 inhabitants $(0.7160)$, which is probably due to the fact that residents prefer the majority of formalities to do online and obtain information in the same way. Television advertising and whisper marketing most appeal to tourists from medium-sized cities with 20 to 100 thousand inhabitants. In this case, the classification function achieved values 0.6169 and 0.5957 , respectively. A slightly lower level $(0.5807)$ in whisper marketing, the classification function achieved in the case of people from small towns up to 20,000 inhabitants (Tab. 1).

Then, the tourists were asked about determinants that decide about buying a tourist event in a given travel agency. The model included 8 out of 9 factors, to which respondents pay attention. Statistically significant effects of individual discriminating factors, from the highest to the smallest, were: a well-known brand that generates widespread trust among customers ( $F=127.5856, p<0.001)$, office recommendation by friends $(F=102.1669$, $p<0.001)$, location ( $F=94.2064, p<0.001)$, rich offer $(F=91.6945, p<0.001)$, adjustment of the offer to individual needs ( $F=27.0767$, $p<0.001)$, competitive price $(F=24.5881$, $p=0.023)$, professional and fast customer service $(F=13,8298, p<0.001)$, equipment, interior design $(F=7.9176, p=0.003)$ (Tab. 2). The tourist habits for a given travel agency did not qualify for the model $(F=1.697, p=0.162)$.

Classification function achieved the highest value by the factor: travel agent's recommendation by friends. This factor is the most important for both people living in the countryside (2.5736), as well as in small towns up to 20,000 inhabitants (2.5188). The well-known brand is also of great importance, especially for people living in small towns (2.2134). Price is another factor that plays a major role. Customers will choose a travel agency that will offer them a better price. The classification function has quite a high value (1.6862) for people living in the countryside. The rich offer of a travel agency is important for people living in large urban agglomerations over 100,000 inhabitants. The classification function in this case has assumed a high value of 2.1645 . The same group of clients draws attention to the adjustment of the offer to individual needs of tourists (0.9890). On the other hand, people from medium-sized cities,

Tab. 1: Sources of searching for information about the travel agency,
taking into account respondents' place of residence

\begin{tabular}{|c|c|c|c|c|c|c|c|}
\hline \multirow[b]{2}{*}{ Specification } & \multicolumn{3}{|c|}{$\begin{array}{c}\text { Model of discriminant analysis } \\
\text { Wilks } \lambda: 0.921 \\
F(24.304)=3.643 ; p<0.001\end{array}$} & \multicolumn{4}{|c|}{$\begin{array}{c}\text { Classification function } \\
\text { (place of residence of respondents) }\end{array}$} \\
\hline & Wilks $\lambda$ & $\mathbf{F}$ & $p$ & $\begin{array}{l}\text { Village } \\
p=0.241\end{array}$ & $\begin{array}{c}\text { Town up to } \\
20 \text { thousand } \\
\text { residents } \\
p=0.186\end{array}$ & $\begin{array}{l}\text { City from } 20 \text { to } \\
100 \text { thousand } \\
\text { residents } \\
p=0.222\end{array}$ & $\begin{array}{l}\text { City over } 100 \\
\text { thousand } \\
\text { residents } \\
p=0.351\end{array}$ \\
\hline Internet, social media & 0.9522 & 11.7876 & $<0.001$ & 0.3524 & 0.4058 & 0.5203 & 0.7160 \\
\hline TV commercial & 0.9311 & 3.7985 & 0.010 & 0.3399 & 0.4855 & 0.6169 & 0.3496 \\
\hline Whisper marketing & 0.9294 & 3.1506 & 0.024 & 0.4539 & 0.5807 & 0.5957 & 0.3579 \\
\hline Constant & & & & -12.4575 & -13.8125 & -13.9487 & -13.3073 \\
\hline
\end{tabular}




\begin{tabular}{|c|c|c|c|c|c|c|c|}
\hline \multirow[b]{2}{*}{ Factor } & \multicolumn{3}{|c|}{$\begin{array}{c}\text { Model of discriminant analysis } \\
\text { Wilks } \lambda: 0.2633 ; \\
F(24.3043)=74.077 ; p<0.001\end{array}$} & \multicolumn{4}{|c|}{$\begin{array}{l}\text { Classification function } \\
\text { (place of residence of respondents) }\end{array}$} \\
\hline & Wilks $\lambda$ & $\mathbf{F}$ & $\mathrm{p}$ & $\begin{array}{c}\text { Village } \\
p=0.241\end{array}$ & $\begin{array}{l}\text { Town up to } \\
20 \text { thousand } \\
\text { residents } \\
p=0.186\end{array}$ & $\begin{array}{c}\text { City from } 20 \text { to } \\
100 \text { thousand } \\
\text { residents } \\
p=0.222\end{array}$ & $\begin{array}{c}\text { City over } 100 \\
\text { thousand resi- } \\
\text { dents } \\
p=0.351\end{array}$ \\
\hline Known brand & 0.3594 & 127.5856 & $<0.001$ & 0.5994 & 2.2134 & 0.6153 & 0.6643 \\
\hline $\begin{array}{l}\text { Recommended } \\
\text { by friends }\end{array}$ & 0.3402 & 102.1669 & $<0.001$ & 2.5736 & 2.5188 & 1.1392 & 1.3726 \\
\hline Location & 0.3342 & 94.2064 & $<0.001$ & 0.5918 & 0.5802 & 1.6184 & 0.5603 \\
\hline Rich offer & 0.3323 & 91.6945 & $<0.001$ & 0.8466 & 1.0700 & 1.1597 & 2.1645 \\
\hline Competitive price & 0.2818 & 24.5881 & $<0.001$ & 1.6862 & 1.1038 & 1.2536 & 0.9234 \\
\hline $\begin{array}{l}\text { Tailoring the offer to } \\
\text { individual needs }\end{array}$ & 0.2837 & 27.0767 & $<0.001$ & 0.4619 & 0.4000 & 0.3186 & 0.9890 \\
\hline $\begin{array}{l}\text { Professional and fast } \\
\text { service }\end{array}$ & 0.2737 & 13.8298 & $<0.001$ & 0.2234 & 0.6315 & 0.0434 & 0.0047 \\
\hline $\begin{array}{l}\text { Furnishings and } \\
\text { decoration of the } \\
\text { office }\end{array}$ & 0.2693 & 7.9176 & 0.003 & 0.3827 & 0.2131 & 0.2239 & 0.0542 \\
\hline Constant & & & & -14.9734 & -16.3703 & -12.7949 & -13.9315 \\
\hline
\end{tabular}

Source: own study based on surveys

\section{Tab. 3: The purpose of tourist trips, taking into account respondents' place of residence}

\begin{tabular}{|c|c|c|c|c|c|c|c|}
\hline \multirow{2}{*}{ Goals of the trip } & \multicolumn{3}{|c|}{$\begin{array}{c}\text { Model of discriminant analysis } \\
\text { Wilks } \lambda: 0.341 \\
F(24.304)=56.889 ; p<0.001\end{array}$} & \multicolumn{4}{|c|}{$\begin{array}{l}\text { Classification function } \\
\text { (place of residence of respondents) }\end{array}$} \\
\hline & Wilks $\lambda$ & $F$ & $\mathbf{p}$ & $\begin{array}{l}\text { Village } \\
p=0.241\end{array}$ & $\begin{array}{l}\text { Town up to } \\
20 \text { thousand } \\
\text { residents } \\
p=0.186\end{array}$ & $\begin{array}{l}\text { City from } 20 \text { to } \\
100 \text { thousand } \\
\text { residents } \\
p=0.222\end{array}$ & $\begin{array}{c}\text { City over } 100 \\
\text { thousand resi- } \\
\text { dents } \\
p=0.351\end{array}$ \\
\hline Religious & 0.5417 & 205.3438 & $<0.001$ & 2.5317 & 1.0446 & 1.0915 & 0.6888 \\
\hline Business & 0.4208 & 81.4115 & $<0.001$ & 0.7408 & 0.9076 & 1.0937 & 1.9821 \\
\hline Health & 0.4099 & 70.3188 & $<0.001$ & 0.6771 & 0.9080 & 0.9276 & 1.8048 \\
\hline Educational & 0.3767 & 36.2850 & $<0.001$ & 0.2106 & 0.8520 & 1.0341 & 0.4393 \\
\hline Rest (passive) & 0.3473 & 6.1767 & 0.003 & 2.9005 & 2.8816 & 3.2331 & 3.0501 \\
\hline Entertainment & 0.3439 & 2.6350 & 0.049 & 1.0566 & 0.9307 & 0.7979 & 0.9640 \\
\hline Constant & & & & -22.5416 & -19.2616 & -20.9467 & -24.1352 \\
\hline
\end{tabular}


from 20 to 100 thousand residents (1.6184), pay attention to the location. Here, customers choose mainly those travel agencies, where it is easy to reach by public transport or car, having their own car park, located near the residence or work of customers. Professional and fast service had a smaller importance for tourists using travel agency services. This factor is mainly attracted by people from small towns (0.6315). The least important is the equipment and decoration of the office. In this case, the classification function assumed the value 0.3827 for people living in the countryside, and only 0.0542 for people living in big cities (Tab. 2).

Getting familiar with the destination is a very important element during the preparation of the offer by tour operators to the individual needs of tourists, hence in the next stage of the research, respondents were asked about the main themes of tourist travel purchased in travel agencies (Tab. 3).

Model of discriminatory function included 6 out of 8 purposes of traveling organized by the organizer of tourism: religious, i.e. travels with religious and cognitive motifs $(F=205.3438$, $p<0.001$ ), business (business trips), it should be noted that in this case, booking of airline tickets or beds is mainly made by travel agency $(F=81.4115, p<0.001)$, health, aimed at improving or maintaining someone's health $(F=70.3188, p<0.001)$, educational (learning of foreign language, culture, history) ( $F=36.2850, p<0.001$ ), holiday (passive) stay in a tourist resort, focused mainly on sunbathing ( $F=6.1767, p=0.003$ ), entertainment purposes (trips to amusement parks, golf courses, water parks, sports matches, etc.) $(F=2.6350$, $p=0.049$ ). Apart from the model, there were adventure goals, i.e. tourist trips organized in unusual conditions (survival) ( $F=0.7719$, $\mathrm{p}=0.510$ ) and recreational (ski, canoeing, sailing, etc.) $(F=1.2134, p>0.304)$ (Tab. 3).

The classification function has reached the highest value with the rest, passive purpose. At $p=0.003$, the greatest enthusiasm for sunbathing was expressed by people coming from medium (3.2331) and large (3.0501) cities. Purchases of tourist events in travel agencies for religious purposes were more often performed by people from village (2.5317) than from cities. Quite a large value was achieved by classification function especially for tourists living in large cities for the business (1.9821) and health goal (1.8048). The lower classification value was obtained for educational purposes. At $p<0.001$, such declarations were more frequently reported by people living in mediumsized (1.0341) than in large cities $(0.4393)$ or rural areas (0.2106). Small differences in the classification functions were noted at trips to amusement parks, golf courses, water parks, sports matches, etc. The highest classification function was achieved by rural residents (1.0556) and large cities (0.9640), then small towns (0.9307) and the lowest - by people from medium-sized cities (0.7979) (Tab. 3).

\section{Discussion}

Increased competition between tourism organizers helps to build better customer relationships (Morgan \& Rego, 2006). These relationships are important in wanting to drag customers to them and ensure their loyalty. Mittal and Lassar (1998) point out that travel agencies should do everything to ensure customer loyalty, because they are less sensitive to prices and the cost of maintaining loyal customers is lower than attracting new ones. In addition, loyal customers are a stable source of profits. Therefore, ensuring customer loyalty should be the strategic goal of every travel agency (Palamidovska-Sterjadovska \& Ciunova-Shuleska, 2017; Pan et al., 2012). However, this is not an easy task, as Huang et al. (2011) and Gonçalves-Sampaio (2012) indicate. One of the conditions for gaining customer loyalty is to know the determinants of choosing a given tourism organizer by a tourist, why one in bestowed with trust while another not (Nikolova \& Hassan, 2013; Perdue, 2002). Research by Berry et al. (2002) and Chih-Wen (2016) showed that tourism organizers should provide unforgettable, satisfying and unusual experiences to their clients by matching their expectations with their offers (Diaz et al., 2017). However, majority of global research focuses on customer segmentation due to age, income or marital status (Hudson \& Shephard, 1998; Klenosky et al., 1993; Konu et al., 2011; Riddington et al., 2000; Seyidov \& Adomaitienè, 2016; Won et al., 2008), while not many of them pay attention to the respondents' place of residence (village, town, big city). Polish research studies carry out partial, but not comprehensive, studies. For example, Uglis and Guth (2015) show that the factor that significantly differentiates tourism activity is the 
place of residence class. The authors show that the choice of travel agency by inhabitants of Polish villages and small towns is mainly influenced by the price, and information about the travel agency is searched by respondents through the Internet and among friends. However, this study did not include research among middle and large cities. Petrykowska's (2010) research shows that the most important factors that influence the selection of a travel agency among residents of medium and large cities is the price (91\%), the quality of customer service $(91 \%)$, and slightly smaller is the wellknown brand $(85 \%)$ and attractiveness of the offer $(76 \%)$. Location (43\%) and travel agency equipment were the least important $(42 \%)$. The author also points out that among the quality of customer service, there is a clear and understandable message of information, knowledge and competence as well as the courtesy of the staff. Research carried out by Mazurek-Kusiak (2012) revealed that the speed of customer service is also important. Research of the author of the paper indicates that for people living in villages and small towns, the most important thing is the recommendation of a travel agency by friends, a well-known brand to which tourists are convinced and a price. For people from medium-sized cities, location of travel agency is very important, and the inhabitants of large cities pay particular attention to the rich offer of travel agencies and adjustment of the tourist event to individual needs of clients. The least important is the equipment and decoration of the office. It should also be remembered that there are no travel agencies in the countryside. Residents of a rural village will usually use the services of travel agencies located in small towns neighboring the given village.

According to Uglis and Guth (2015), the main purpose of tourist trips among inhabitants of small towns and villages is tourism and leisure, and less frequently, health or religious motifs were mentioned as targets. Karbowiak (2006) also indicates that a tourist - resident of the village, mainly goes to visit family or friends, stays in peace and quiet away from people, as well as visits places of religious worship. Residents of small towns most often used passive recreation, social life as well as therapeutic and sanatorium treatments during their trips. On the other hand, city residents, as the main purpose of trips, pointed to sightseeing tourism, passive rest, but also to improve physical condition and to engage in qualified tourism. Similar conclusions were drawn by Łaciak (2005). The study of the author of present paper also showed similar differences in tourist trips due to the respondents' place of residence, with the difference that the main purpose of trips of village residents are pilgrimages and places of religious worship.

\section{Conclusion}

Tourism organizers located in large cities wanting to attract clients should have a wide range of travels in their catalogs, but at the same time, be flexible in composing tourist events, adapting them to individual customer requirements. In addition to traditional leisure events, they should have in their offer business events such as motivational or integrating the employees and events aimed at improving health, such as wellness centers. The main communication with customers should be carried out through social media and they have to run a very good website.

Tourism organizers located in mediumsized cities should pay attention to the location of their office, so that potential customers would not have a problem with getting public transport or finding a parking space if driving their own car. The offer of these travel agencies should include, apart from holiday stays, a wide range of educational trips, e.g. language, culinary etc. The promotion should be carried out through TV channels and in the form of whisper marketing.

Tourism organizers located in small towns should pay attention to the high quality of customer service, because customers will usually come here on the instructions of their friends. The competitive price and well-known brand is also important. The offer of these travel agencies should include, above all, leisure holidays, trips related to religious worship and trips to places of entertainment. The promotion should be carried out through word-of-mouth marketing.

The highest values is travel agency communication with a potential client via internet, including social media. This factor is most important for residents of large cities over 100,000 inhabitants (0.7160). And the highest determinate taken into consideration when choosing a travel agency is travel agent's recommendation by friends. This factor is the most important for both people living in the 
countryside (2.5736), as well as in small towns up to 20,000 inhabitants (2.5188).

\section{References}

Aguiar-Quintana, T., Moreno-Gil, S., \& Picazo-Peral, P. (2016). How could traditional travel agencies improve their competitiveness and survive? A qualitative study in Spain. Tourism Management Perspectives, 20, 98-108. https://doi.org/10.1016/j.tmp.2016.07.011

Barros, C. P., \& Matias, A. (2006). Assessing the efficiency of travel agencies with a stochastic cost frontier: A Portuguese case study. International Journal of Tourism Research, 8(5), 367-379. https://doi.org/10.1002/jtr.578

Bennet, M. M. (1993). Information technology and travel agency: A customer service perspective. Tourism Management, 14(4), 259-266. https://doi.org/10.1016/02615177(93)90060-X

Berry, L. L., Seiders, K., \& Grewal, D. (2002). Understanding service convenience. Journal of Marketing, 66(3), 1-17. https://doi. org/10.1509/jmkg.66.3.1.18505

Byszewska-Dawidek,

$\mathrm{M}$.

(2015).

Ekonomiczna sytuacja biur podróży na polskim rynku w latach 2006-2012, Kwartalnik Naukowy Uczelni Vistula, 2(44), 77-89.

Castillo-Manzano, J. I., \& López-Valpuesta, L. (2010). The decline of the traditional travel agent model. Transportation Research Part E: Logistics and Transportation Review, 46(5), 639-649. https://doi.org/10.1016/j. tre.2009.12.009

Del Chiappa, G. (2013). Internet versus travel agencies: The perception of different groups of Italian online buyers. Journal of Vacation Marketing, 19(1), 55-66. https://doi. org/10.1177/1356766712466613

Díaz, E., Gómez M., Martín-Consuegra, D., \& Molina, A. (2017). The Effects of Perceived Satisfaction with Service Recovery Efforts: a Study in a Hotel Setting. E\&M Ekonomics and Management, 20(4), 203-218. https://doi. org/10.15240/tul/001/2017-4-014

Frias, D. M., Rodríguez, M. A., \& Castañeda, J. A. (2008). Internet vs. travel agencies on previsit destination image formation: An information processing view. Tourism Management, 29(1), 163-179. https://doi.org/10.1016/j.tourman.2007.02.020

Fuentes, R., \& Alvarez-Suarez, A. (2012). Productivity of travel agencies in Spain: The case of Alicante. The Services Industries Journal, 32(16), 2623-2640. https://doi.org/10 $.1080 / 02642069.2011 .596930$

Galhanone, R. F., Marques, J. A., Toledo, G. L., \& Mazzon, J. A. (2010). Turismo de lujo e internet: Oportunidades para las agencias de viajes. Estudios y perspectivas en turismo, 19(6), 888-908.

Gonçalves, H. M., \& Sampaio, P. (2012). The customer satisfaction-customer loyalty relationship: Reassessing customer and relational characteristics moderating effects. Management Decision, 50(9), 1509-1526. https://doi.org/10.1108/00251741211266660

Gustafson, P. (2012). Managing business travel: Developments and dilemmas in corporate travel management. Tourism Management, 33(2), 276-284. https://doi.org/10.1016/j. tourman.2011.03.006

Huang, L., Yung, C. Y., \& Yang, E. (2011). How do travel agencies obtain a competitive advantage?: Through a travel blog marketing channel. Journal of Vacation Marketing, 17(2), 139-149. https://doi. org/10.1177/1356766710392737

Hudson, S., \& Shephard, G. W. H. (1998). Measuring service quality at tourist destinations: An application of importance-performance analysis to an Alpine ski resort. Journal of Travel and Tourism Marketing, 7(3), 61-77. https://doi. org/10.1300/J073v07n03_04

Chen, Y. H., \& Kang, H. H. (2015). Analysis of tourist flow from the us to Taiwan. Acta Oeconomica, 65(S2), 369-384. https://doi. org/10.1556/032.65.2015.S2.27

Ilbery, B., Saxena, G., \& Kneafsey, M. (2007). Exploring tourists and gatekeepers' attitudes towards integrated rural tourism in the England-Wales border region. Tourism Geographies, 9(4), 441-468. https://doi. org/10.1080/14616680701647667

Jayanti, R., \& Jackson, A. (1991). Service satisfaction: An exploratory investigation of three models. Advances in Consumer Research, 18(1), 603-609.

Karbowiak, K. (2006). Uczestnictwo Polaków - mieszkańców miast i wsi - w wyjazdach turystycznych - podobieństwa i różnice. Roczniki Nauk Rolniczych, Seria G, 93(1), 152-160.

Klenosky, D. B., Gengler, C. E., \& Mulvey, M. (1993). Understanding the factors influencing ski destination choice: a means-end analytic approach. Journal of Leisure Research, 25(4), 
362-379. https://doi.org/10.1080/00222216.19 93.11969934

Köksal, C. D., \& Aksu, A. A. (2007). Efficiency evaluation of A-group travel agencies with data envelopment analysis (DEA). A case study in the Antalya region, Turkey. Tourism Management, 28(3), 830-834. https://doi. org/10.1016/j.tourman.2006.05.013

Konu, H., Laukkanen, T., \& Komppula, T. (2011). Attributes of ski destination choice: A Finnish survey. Tourism management, 32(5), 1096-1105.

Kumar, V., Pozza. I. D., \& Ganesh, J. (2013). Revisiting the satisfaction-loyalty relationship: Empirical generalizations and directions for future research. Journal of Retailing, 89(3), 246-262. https://doi.org/10.1016/j.jretai.2013.02.001

Kuo, N. T., Chang, K. C., Cheng, Y. S., \& Lai, C. H. (2013). How service quality affects customer loyalty in the travel agency: The effects of customer satisfaction, service recovery, and perceived value. Asia Pacific Journal of Tourism Research, 18(7), 803-822. https://doi.org/10.1080/10941665.2012.708352

Lacalle, L. (2013). Agencias de viajes en España. Una industria convulsa. Papers de turismo, 54, 122-138.

Łaciak, J. (2005). Uczestnictwo Polaków w wyjazdach turystycznych. Warszawa: Instytut Turystyki.

Lai, I. K. W. (2014). The role of service quality, perceived value, and relationship quality in enhancing customer loyalty in the travel agency sector. Journal of Travel \& Tourism Marketing, 31(3), 417-442. https://doi.org/10.1 080/10548408.2014.883346

Lam, T., \& Zhang, H. Q. (1999). Service quality of travel agents: The case of travel agents in Hong Kong. Tourism Management, 20(3), 341-349. https://doi.org/10.1016/S02615177(98)00118-6

Mańko, K. (2012). Współczesne tendencje rozwojowe biur podróży w Polsce. Zeszyty Naukowe Uniwersytetu Szczecińskiego, Problemy Zarządzania, Finansów i Marketingu, 2012(27), 211-220.

Martínez-Caro, L., \& Martínez-García, J. A. (2008). Developing a multidimensional and hierarchical service quality model for the travel agency industry. Tourism Management, 29(4), 706-720. https://doi.org/10.1016/j. tourman.2007.07.014

Mazurek-Kusiak, A. (2012). Popyt na usługi tradycyjnych biur podróży a jakość obsługi klienta na przykładzie lubelskiego rynku biur podróży. Ekonomiczne Problemy Usług, 84(1), 461-469.

Mazurek-Kusiak, A. (2017). Characteristic of demand for recreational aktivity. Rozprawy Społeczne, 11(4), 113-119. https://doi. org/10.29316/rs.2017.36

Millan, A., \& Esteban, A. (2004). Development of a multiple-item scale for measuring customer satisfaction in travel agencies services. Tourism Management, 25(5), 533-546. https://doi.org/10.1016/j. tourman.2003.07.002

Mittal, B., \& Lassar, W. M. (1998). Why do customers switch? The dynamics of satisfaction versus loyalty. Journal of Services Marketing, 12(3), 177-194. https://doi. org/10.1108/08876049810219502

Morgan, N.A., \& Rego, L. L. (2006). The value of different customer satisfaction and loyalty metrics in predicting business performance. Marketing Science, 25(5), 426-439. https://doi. org/10.1287/mksc. 1050.0180

Nikolova, M. S., \& Hassan, S. S. (2013). Nation branding effects on retrospective global evaluation of past travel experiences. Journal of Business Research, 66(6), 752-758. https://doi.org/10.1016/j.jbusres.2011.09.014

O'Connor, P. (1999). Electronic information distribution in tourism and hospitality. New York, NY: CAB International.

Özturan, M., \& Roney, S. A. (2004). Internet use among travel agencies in Turkey: an exploratory study. Tourism Management, 25(2), 259-266. https://doi.org/10.1016/S02615177(03)00097-9

Palamidovska-Sterjadovska, N., \& Ciunova-Shuleska, A. (2017). An Integrated Model of Customer Loyalty in the Macedonian Mobile Service Market. E\&M Ekonomics and Management, 20(2), 199-215. https://dx.doi. org/10.15240/tul/001/2017-2-015

Pan, Y., Sheng, S., \& Xie, F. T. (2012). Antecedents of customer loyalty: An empirical synthesis and reexamination. Journal of Retailing and Consumer Services, 19(1), 150-158. https://doi.org/10.1016/j. jretconser.2011.11.004

Perdue, R. (2002). Perishability, yield management, and cross-product elasticity: A case study of deep discount season passes in the Colorado ski industry. Journal of Travel Research, 41(1), 15-22. https://doi. org/10.1177/0047287502041001003 
Petrykowska, J. (2010). Czynniki determinujące wybór oferty biura podróży - wyniki badania. Problemy Zarządzania, Finansów i Marketingu, 16, 195-202.

Piotrowska, B. (2007). Wartość firmy w ustawie o rachunkowości i MSSF. Doradca Podatnika, 17(1), 12-21.

Riddington, G., Sinclair, C., \& Milne, N. (2000). Modelling choice and switching behavior between Scottish ski centres. Applied Economics, 32(8), 1011-1018. https://doi. org/10.1080/000368400322066

Rudawska, E. (2010). Zmiany zachowań konsumenckich w kryzysie - mity czy fakty? Problemy Zarządzania, Finansów i Marketingu, 15, 283-290.

Ryan, C., \& Cliff, A. (1997). Do travel agencies measure up to customer expectation? An empirical investigation of travel agencies' service quality as measured by SERVQUAL. Journal of Travel \& Tourism Marketing, 6(2), 1-31. https://doi.org/10.1300/J073v06n02_01

Seyidov, J., \& Adomaitienè, R. (2016). Factors influencing local tourists' decisionmaking on choosing a destination: a case of Azerbaijan. Ekonomika, 95(3), 112-127. https://doi.org/10.15388/ekon.2016.3.10332

Silva, G. M., \& Gonçalves, H. M. (2016). Causal recipes for customer loyalty to travel agencies: Differences between online and offline customers. Journal of Business Research, 69(11), 5512-5518. https://doi. org/10.1016/j.jbusres.2016.04.163

Sobolewski, H., \& Bober, P. (2013). Touroperatorzy w Polsce a wartość przedsiębiorstw turystycznych. Zeszyty Naukowe Uniwersytetu Szczecińskiego Nr. 786, Finanse, Rynki i Ubezpieczenia, 64(1), 427-435.

Tabachnik, B. G., \& Fidell, L. S. (1996). Using Multivariate Statistics. New York, NY: HarperCollins Publishers.

Tse, D. K., \& Wilton, P. C. (1988). Models of consumer satisfaction formation: An extension. Journal of Marketing Research, 25(2), 204-212. https://doi.org/10.1177/002224378802500209

Uglis, J., \& Guth, P. (2015). Determinanty aktywności mieszkańców małych miast i wis: studium przypadku. Ekonomiczne problemy turystyki, 1(29), 303-314.

Wang, H. Y., \& Wang, S. H. (2010). Predicting mobile hotel reservation adoption: Insight from a perceived value standpoint. International Journal of Hospitality Management, 29(4), 598-608. https://doi.org/10.1016/j.jhm.2009.11.001

Won, D., Bang, H., \& Shonk, D. J. (2008). Relative importance of factors involved in choosing a regional ski destination: Influence of consumption situation and recreation specialization. Journal of Sport and Tourism, 13(4), 249-271. https://doi. org/10.1080/14775080802577185

Wu, C.-W. (2016). Destination loyalty modeling of the global tourism. Journal of Business Research, 69(9), 2213-2219. https://doi.org/10.1016/j.jbusres.2015.12.032

Zdon-Korzeniowska, M., \& Rachwał, T. (2011). Turystyka w warunkach światowego kryzysu gospodarczego. Prace Komisji Geografii Przemysłu, 18, 116-128. 